\title{
Diagnosis and treatment of adenomyosis
}

\author{
(Ebernella) Shirin Dason MD, Crystal Chan MD MSc, Mara Sobel MD MSc
}

Cite as: CMAJ 2021 February 16;193:E242. doi: 10.1503/cmaj.201607

CMAJ Podcasts: author interview at www.cmaj.ca/lookup/doi/10.1503/cmaj.201607/tab-related-content

\section{Adenomyosis is a common cause of dysmenorrhea and heavy \\ menstrual bleeding}

Adenomyosis is a benign gynecological disorder characterized by aberrant development of endometrial glands and stroma within the myometrium, causing inflammation and neuroangiogenesis. ${ }^{1,2}$ Adenomyosis often coexists with other gynecological conditions and may cloud the clinical presentation (Appendix 1, available at www.cmaj.ca/lookup/doi/10.1503/ cmaj.201607/tab-related-content). ${ }^{1}$

2

Adenomyosis can affect any reproductive-aged woman, with incidence and severity increasing with age

Historically thought to affect only older women, adenomyosis is now identifiable on imaging in $30 \%$ of women younger than 40 years. ${ }^{1,2}$ Up to $30 \%$ of women with adenomyosis are asymptomatic and symptoms resolve after menopause; asymptomatic or menopausal women do not require management. ${ }^{1,3,4}$

\section{3}

\section{Transvaginal ultrasound is the first-line diagnostic test for} adenomyosis

All women presenting with dysmenorrhea or heavy menstrual bleeding should receive a transvaginal ultrasound to assess for adenomyosis as well as to exclude other structural causes (e.g., polyps, fibroids). Transvaginal ultrasound has a sensitivity of $83.8 \%$ and specificity of $63.9 \%$ for adenomyosis, and confirmatory testing with magnetic resonance imaging is usually not required. ${ }^{2}$

Medical management is effective for symptom control in most women with adenomyosis

Empiric therapy may be started before ultrasound results are received. The levonorgestrel intrauterine system is the most-studied treatment, with the largest randomized controlled trial $(n=86)$ showing comparable improvement in hemoglobin and quality of life compared with hysterectomy at 6 months. ${ }^{5}$ Other treatments include tranexamic acid, nonsteroidal anti-inflammatory drugs, combined hormonal contraceptives and other progestins (norethindrone acetate, medroxyprogesterone, dienogest). If initial treatment fails after 3-6 months, referral to a gynecologist is suggested, to consider other medical (i.e., gonadotropin-releasing hormone agonists), interventional or surgical options. ${ }^{1,3,5}$

\section{Adenomyosis, whether symptomatic or asymptomatic, may} affect fertility

Referral to a fertility specialist is appropriate for patients presenting with subfertility or recurrent miscarriage, especially after the age of 35 years.

\section{References}

1. Gordts S, Grimbizis G, Campo R. Symptoms and classification of uterine adenomyosis, including the place of hysteroscopy in diagnosis. Fertil Steril 2018;109:380-8.e1.

2. Chapron C, Vannuccini S, Santulli $P$, et al. Diagnosing adenomyosis: an integrated clinical and imaging approach. Hum Reprod Update 2020;26:392-411.

3. Vannuccini S, Luisi S, Tosti C, et al. Role of medical therapy in the management of uterine adenomyosis. Fertil Steril 2018; 109:398-405.

4. Yu O, Schulze-Rath R, Grafton J, et al. Adenomyosis incidence, prevalence and treatment: United States population-based study 2006-2015. Am J Obstet Gynecol 2020;223:94.e1-10.

5. Benetti-Pinto CL, de Mira TAA, Yela DA, et al. Pharmacological treatment for symptomatic adenomyosis: a systematic review. Rev Bras Ginecol Obstet 2019;41:564-74.

\section{Competing interests: None declared.}

This article has been peer reviewed.

Affiliations: Department of Obstetrics and Gynaecology (Dason), University of Toronto; Department of Obstetrics and Gynaecology (Sobel, Chan), Mount Sinai Hospital, Toronto, Ont.

Content licence: This is an Open Access article distributed in accordance with the terms of the Creative Commons Attribution (CC BY-NC-ND 4.0) licence, which permits use, distribution and reproduction in any medium, provided that the original publication is properly cited, the use is noncommercial (i.e., research or educational use), and no modifications or adaptations are made. See: https://creativecommons. org/licenses/by-nc-nd/4.0/

Correspondence to: Ebernella Dason, shirin.dason@mail.utoronto.ca

CMAJ invites submissions to "Five things to know about ..." Submit manuscripts online at http://mc. manuscriptcentral.com/cmaj 